\title{
Genomic and Epigenomic Alterations in Cancer
}

\author{
Balabhadrapatruni V.S.K. Chakravarthi, Saroj Nepal, and Sooryanarayana Varambally
}

From the Department of Pathology and Comprehensive Cancer Center, University of Alabama at Birmingham, Birmingham, Alabama

Accepted for publication February 23, 2016.

Address correspondence to Sooryanarayana Varambally, Ph.D., Department of Pathology, University of Alabama at Birmingham, Wallace Tumor Institute, Room \#430,

Birmingham, AL 35233.

E-mail: soorya@uab.edu.

\begin{abstract}
Multiple genetic and epigenetic events characterize tumor progression and define the identity of the tumors. Advances in high-throughput technologies, like gene expression profiling, next-generation sequencing, proteomics, and metabolomics, have enabled detailed molecular characterization of various tumors. The integration and analyses of these high-throughput data have unraveled many novel molecular aberrations and network alterations in tumors. These molecular alterations include multiple cancer-driving mutations, gene fusions, amplification, deletion, and post-translational modifications, among others. Many of these genomic events are being used in cancer diagnosis, whereas others are therapeutically targeted with small-molecule inhibitors. Multiple genes/enzymes that play a role in DNA and histone modifications are also altered in various cancers, changing the epigenomic landscape during cancer initiation and progression. Apart from protein-coding genes, studies are uncovering the critical regulatory roles played by noncoding RNAs and noncoding regions of the genome during cancer progression. Many of these genomic and epigenetic events function in tandem to drive tumor development and metastasis. Concurrent advances in genome-modulating technologies, like gene silencing and genome editing, are providing ability to understand in detail the process of cancer initiation, progression, and signaling as well as opening up avenues for therapeutic targeting. In this review, we discuss some of the recent advances in cancer genomic and epigenomic research. (Am J Pathol 2016, 186: 1724-1735; http://dx.doi.org/10.1016/ j.ajpath.2016.02.023)
\end{abstract}

Cancer is the second most common cause of death in the United States and accounts for nearly one of every four deaths. ${ }^{1}$ The American Cancer Society predicts that in 2016, there will be an estimated 1,685,210 new cancer cases diagnosed and 595,690 cancer deaths in the United States. ${ }^{1}$ There have been tremendous efforts and remarkable advances made to understand and treat this disease. Multiple molecular events are responsible for the initiation and progression of cancer. Change in the DNA sequence of the genome of a cancer cell is one of the major causes for cancer initiation. With the advent of new technologies, it is possible now to obtain a complete DNA sequence of large numbers of cancer genomes and identify the alterations between normal and cancer genomes between patients and between different tumor types. These studies, in addition to identifying other molecular correlates like transcriptome and metabolome, provide insights into the tumor heterogeneity and the history of tumor development.

\section{Gene Mutations}

The DNA sequence of a cancer cell genome generally acquires a set of aberrations or somatic mutations. ${ }^{2}$ These include substitutions, insertions, or deletions of small or large fragments of DNA, genomic amplification, and rearrangements. ${ }^{2}$ Although some of these somatic mutations play a role in cancer initiation and progression, others may act as passenger aberrations. ${ }^{2}$ In addition, completely new DNA sequences are acquired from human papilloma virus, Epstein Barr virus, hepatitis B virus, human T lymphotropic virus, and human herpes virus 8 , which are known to

\footnotetext{
Supported by NIH/National Cancer Institute grants R01CA157845 and R01CA154980 (S.V.).

A guest editor acted as the Editor-in-Chief for this manuscript. No one at the University of Alabama at Birmingham was involved in the peer review or final disposition of this article.

Disclosures: None declared.
} 
contribute to the genesis of one or more types of cancer. ${ }^{3}$ In many human cancers, somatic mutations in the mitochondrial genomes have been documented, although their role is not clear. ${ }^{2}$ The mutations in the cancer genome were acquired by exposure to both internal and external mutagens. Studies have shown that the mutation rates increase in the presence of substantial exogenous mutagenic exposures, like tobacco smoke carcinogens, aflatoxins, and radiation, which are associated with lung, liver, and skin cancers, respectively. ${ }^{2,4}$

Somatic mutations, on the basis of their function, consist of driver mutations, which confer growth advantage to the cancer cells and have been positively selected during cancer development. ${ }^{5}$ On other hand, the passenger mutations are those that neither confer any growth advantage to the cancer cells nor contribute to cancer development. ${ }^{5}$ Thus, the main goal of cancer genome analysis is the identification of mutations in genes that harbor driver mutations. Most of the cancers harbor more than one driver gene mutation. It is suggested that the breast, colorectal, and prostate require five to seven driver mutations for cancer initiation and progression, whereas hematological malignancies may require fewer. ${ }^{6}$ Some of the well-characterized genes carrying mutations include $T P 53, R B 1, E G F R$, and $K R A S$, which are frequently mutated in various cancer types, whereas others are rare and/or restricted to one cancer.

Apart from genomic events that are evident during cancer progression, modifications of the nucleotides, particularly that of the cytosine and post-translational histone modifications, are common in cancer (Figure 1). ${ }^{7}$ These modifications, referred to as epigenetic changes, are independent of alterations in the primary DNA sequence and involve changes in DNA methylation and histone modifications. ${ }^{7}$ In addition, these changes in cancer constitute the cancer epigenome and play crucial roles in control of gene activity and nuclear architecture. ${ }^{8}$ The chromatin-modifying enzymes act on histones in a highly regulated manner. As many as four different DNA modifications and 16 classes of histone modifications have been identified. ${ }^{7}$ Chromatin structure is altered by these modifications both locally and globally, depending on the activity and specificity of the modifying enzymes. These modifications serve multiple purposes during cancer initiation and progression. Some modifications serve as docking sites for specific proteins that can specifically recognize these modifications. Other modifications, like histone $\mathrm{H} 3$ acetylation and methylations, alter the chromatin compaction and relaxation status, leading to repression or activation of transcription, thus regulating gene expression. ${ }^{9}$ In contrast to above, relatively small molecular modifications to amino acid side chains, ubiquitination is a larger covalent modification. H2BK123ub1 modification involves the addition of ubiquitin chain to histone $\mathrm{H} 2 \mathrm{~B}$ and this modification results in regulating transcriptional initiation and elongation, whereas H2AK119ub1 is involved in gene silencing. ${ }^{10}$ Similarly, phosphorylation of histones plays a crucial part of the histone code. Phosphorylated forms of histones, H3S10ph and H2BS32ph, are known to be involved

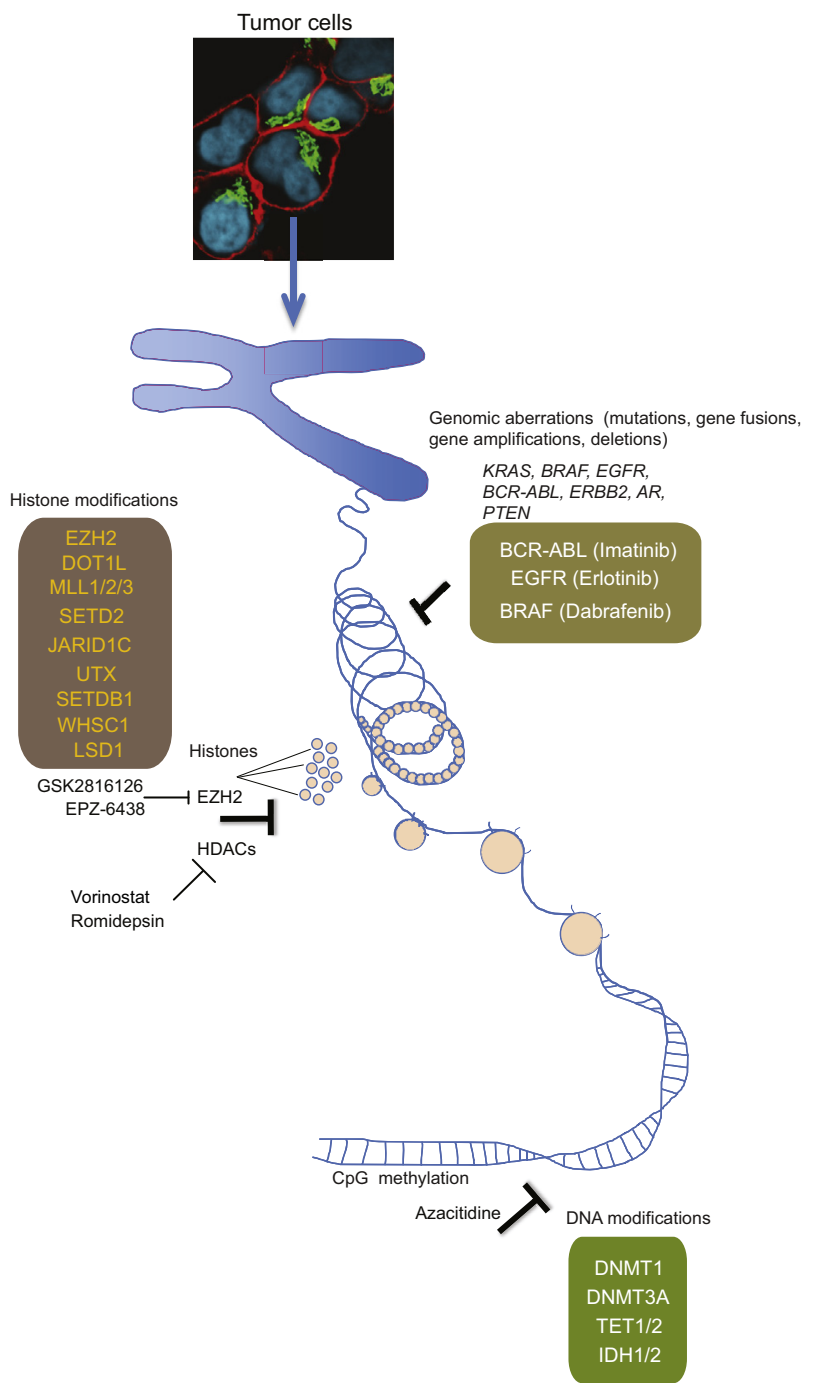

Figure 1 Model depicting genomic and epigenetic events during cancer progression. Numerous genetic events, like gene amplifications, deletions, gene fusions, and mutations of oncogenes and tumor suppressor genes, are common in cancer. In addition, many histone modifiers also show aberrant regulation in cancer. These changes modulate gene expression during cancer progression. DNA methylation and demethylation are also common occurrence in cancer and lead to altered regulation of gene expression. Many of these genomic and epigenetic regulators are effective therapeutic targets in cancer. EGFR, epidermal growth factor receptor.

in the expression of proto-oncogenes, such as $M Y C, J U N$, and FOS. $^{11}$

Hypermethylation of $\mathrm{CpG}$ islands of tumor suppressor genes, such as cyclin-dependent kinase inhibitor $2 \mathrm{~A}$ (CDKN2A), mutL homolog-1 (MLH1), breast cancerassociated-1 (BRCAl), and von Hippel-Lindau (VHL) tumor suppressor, leading to their transcriptional repression, is common in cancer cells. ${ }^{12,13}$ Epigenetic modification of genes may also serve as useful biomarkers, both for diagnosis and therapy. Hypermethylation of the glutathione S-transferase (GSTPI) gene is observed in $85 \%$ of prostate cancers but not in benign prostatic hyperplasia, and thus could serve as a potential biomarker for prostate cancer. ${ }^{14}$ 
The well-studied histone modifications include acetylation, deacetylation, methylation, phosphorylation, and ubiquitylation. ${ }^{15}$ Some of these epigenetic modifications are known to play a role in initiating the clonal expansion of premalignant cells. ${ }^{16}$ It has been postulated that the epigenetic alternations during the earliest stages of prostate and colon cancer and development of other tumors might determine subsequent genetic changes and thereby promote cancer progression. ${ }^{16}$

Whole genome sequencing analysis revealed recurrent somatic mutations in various epigenetic regulators ${ }^{2}$ in different tumors. The lysine (K)-specific demethylase KDM6A (UTX) is mutated in up to 12 histologically distinct cancers $^{17}$ and moreover approximately $90 \%$ of follicular lymphoma cases harbor recurrent mutations in histone methyltransferase KMT2D (MLL2). ${ }^{18}$ The histone H3 lysine 27 trimethylating enzyme, $E Z H 2$, shows recurrent mutation in a subclass of lymphoma. ${ }^{19}$ Interesting correlations between cancer-associated DNA hypermethylation and genes marked with bivalent histone modifications were observed using DNA methylation profiles and chromatin immunoprecipitation-sequencing data, respectively.

\section{Common Genomic and Epigenomic Alterations in Cancer}

Numerous studies revealed a myriad of acquired alterations in cancer. The alternations/mutations are heterogeneous and found among different tumors. Some of the more common genomic alterations include copy number variations, including amplification or deletion of the genomic regions. Again, the genomic sequencing using next-generation sequencing (NGS) technology provided opportunity to characterize genome-wide copy number variations with great resolution. ${ }^{20}$ The genomic aberrations can be specific to short segment of DNA or span over many kb of DNA. These genomic events observed include mutations in the protein-coding genes, which lead to either activation of oncogenes or inactivation of tumor suppressors. In that, nonsynonymous substitution and truncating mutations are of particular interest. Chromosomal rearrangement and gene fusions are another common class of genomic aberrations in cancer. After the discovery of Philadelphia chromosome in 1960 as a specific chromosome change in chronic myeloid leukemia, multiple studies have shown the occurrence of fusion genes in variety of cancers and through many different approaches. ${ }^{21}$ The landmark discovery of $B C R$ $A B L 1$ kinase fusion lead to the discovery of small-molecule inhibitor imatinib (Gleevec) for targeting patients with this fusion gene. ${ }^{21}$ Gene fusions were commonly discovered in hematological malignancies. However, identification of recurrent fusion between promoter of androgen-regulated gene transmembrane protease serine 2 gene (TMPRSS2) with ETS transcription factor $E R G^{22}$ as a common event in prostate cancer is suggested, for the first time, a highly recurrent gene fusion event in a common epithelial tumor. These common gene fusions in prostate cancer involve transmembrane protease serine 2 gene (TMPRSS2) with two genes encoding ETS transcription factors, either v-ets avian erythroblastosis virus E26 oncogene homologue (ERG; resulting in the TMPRSS2-ERG fusion gene) or ets variant 1 (ETV1; resulting in the TMPRSS2-ETV1 fusion gene). ${ }^{22,23}$ Sequencing of genomes and transcriptomes has enabled the identification of additional gene fusions in other common epithelial tumors. ${ }^{24}$ Some of the gene fusions identified in epithelial tumors include RAF kinase pathway gene fusion, including $B R A F$ in gastric and prostate cancer ${ }^{25}$ and $E M L 4-A L K$ gene fusion non-small-cell lung cancer ${ }^{26}$ among others. Many of the fusion genes are therapeutically targeted, and the US Food and Drug Administration (FDA) has approved drugs against proteins encoded by EMLA-ALK, BCR-ABL1, COL1A1-PDGFRB, FIPIL1PDGFRA, and PDGFR gene fusions in malignancy. ${ }^{21}$ Chromosomal deletions and homozygous null mutations involving the TET2 locus, and deletion and $I D H 1 / 2$ (isocitrate dehydrogenase $[\mathrm{NADP}(+)] 1$, cytosolic and isocitrate dehydrogenase $[\mathrm{NADP}(+)] 2$, mitochondrial) gene mutations have been described in various myeloid and lymphoid malignancies. ${ }^{27,28}$

As discussed earlier, epigenetic modifications generally regulate the gene expression and thereby altering properties and behavior of the cell. Mechanisms of epigenetic gene activation and repression include histone and DNA modifications. These modifications play essential roles in epigenetically transmitting transcriptional memory. The epigenetic memory inside a cell is stored in the form of a histone code that decides the structure and activity of different chromatin regions. ${ }^{15}$ Being a global regulator of gene expression, most epigenetic alterations profoundly affect the cancer progression. ${ }^{13}$ The ensuing epigenetic changes lead to perturbations in gene expression, particularly silencing of tumor suppressor genes and activation of oncogenes.

Genome-wide hypomethylation and site-specific $\mathrm{CpG}$ island promoter hypermethylation are prominent DNA methylation changes that occur in cancer. It has been shown that promoter hypomethylation causes activation of oncogenes, such as $R R A S, S 100 P$, and melanoma antigen family A1 (MAGEA1) in gastric, pancreatic, and hepatocellular carcinoma, respectively. ${ }^{29}$ It has been shown that the hypomethylation occurs in introns, $\mathrm{CpG}$ poor promoters, repetitive elements, or retrotransposons. ${ }^{8}$ In addition, site-specific hypermethylation causes silencing of tumor suppressor genes, such as BRCA1, CDKN2A, and $M L H 1$ in many cancer types, thereby aiding tumorigenesis. DNA hypermethylation is also known to cause silencing of transcription factors. In colon cancers, it has been shown that GATA4 and 5 are silenced, whereas in esophageal cancers $R U N X 3$ undergoes hypermethylation leading to silencing. ${ }^{8}$ Studies have suggested a role for nucleosome positioning in cancer. These observations suggest that DNA methylation-induced repression of tumorsuppressor genes could be mediated through nucleosome 
occupancy at the transcription start site. ${ }^{30}$ One of the key features for tumor stratification is on the basis of DNA hypermethylation in CpG-rich promoters and is now recognized as a common feature of human cancers, which is also called as $\mathrm{CpG}$ island methylator phenotype. $\mathrm{CpG}$ island methylator phenotype refers to the concordant methylation of a group of genes, and this has been confirmed in colorectal cancer and has also been observed in glioblastomas, gastric, liver, and pancreatic cancer, among others. ${ }^{31}$ Accordingly, human cancers can be classified on the basis of the extent of methylation.

A growing number of studies have shown the effect of histone modifications in tumor progression. Common modifications of histones include acetyl and methyl group addition or removal, ubiquitination, and phosphorylation. In general, loss of histone acetylation at lysine 16 and alteration in $\mathrm{H} 3 \mathrm{~K} 4$, H3K9, and H3K27 methylation patterns have been observed in many cancers. Histone methyl transferases, such as EZH2, SETDB1, WHSC1 (MMSET), and others, are overexpressed in many cancers, including common epithelial tumors like breast and prostate cancer. ${ }^{32-35}$ Common histone-modifying enzymes amplified, overexpressed, or mutated in cancer are shown in Table 1. EZH2, the catalytic subunit of the polycomb repressive complex 2 , suppresses gene expression through methylation of histone $\mathrm{H} 3$ on lysine $27 .{ }^{50}$

Somatic mutations in its enzymatic domain result in activation and increased trimethylation of histone $\mathrm{H} 3$ at lysine 27 (H3K27me3) in cancer. Gain-of-function mutation at Y641 and A677 residues in SET domain of EZH2 have been characterized in follicular lymphoma and diffuse large B-cell lymphoma of germinal center origin. ${ }^{19}$ EZH2-activating mutation at Y641 has also been reported in melanoma. ${ }^{51}$ EZH2 inhibitors such as GSK-126 are highly effective in suppressing cell proliferation and xenograft growth in EZH2 mutant tumors. ${ }^{51}$ Recently, EZH2 inactivating mutation was also shown in myeloid dysplasia syndromes/myeloproliferative neoplasms. ${ }^{51}$ Another important chromatin remodeling complex is Switch/Sucrose Non Fermentable (SWI/SNF), which is commonly dysregulated and plays a tumor suppressive role in cancer. ${ }^{51}$ Nearly $20 \%$ of human cancers have mutations that inactivate SWI/SNF subunits in diverse cancers. ${ }^{52}$ Of particular importance is AT-rich interactive domaincontaining protein 1A (ARIDIA), a subunit of SWI/SNF complex and a tumor suppressor that shows recurrent inactivating mutation either missense or insertion/deletion in many cancer types, such as ovarian clear cell carcinoma, endometrioid carcinoma of the ovary, esophageal adenocarcinoma, bladder, and gastric carcinoma, among others. ${ }^{53}$ Another member of SWI/SNF complex, SMARCA4/BRG1 (SWI/SNF related, matrix associated, actin dependent regulator of chromatin, subfamily A, member 4) is one of the most commonly mutated subunits in non-small-cell lung cancer, Burkitt's lymphoma, medulloblastoma, pancreatic adenocarcinoma, ovarian clear cell carcinoma, occasionally in melanoma, smallcell carcinoma of the ovary, hypercalcemic type, and other tumor types. $^{54}$

\section{Genetic and Epigenetic Diagnosis in Cancer}

Traditional DNA sequencing techniques are commonly used for detecting germline mutations responsible for hereditary forms of cancer. Most diagnostic laboratories use Sanger's chain termination method with dideoxynucleotides to determine DNA sequence. ${ }^{55}$ Another common alternative method is pyrosequencing that relies on detection of pyrophosphate release on nucleotide incorporation. ${ }^{56}$ This method is sensitive and is appropriate for use on short fragmented DNA from formalin-fixed and paraffin-embedded tissue sections. Such first-generation techniques are used to detect clinically relevant small set of known mutations. However, recent advances in genome-wide techniques revolutionized the diagnostic testing area as well. Researchers and clinical laboratories can now investigate the sequence alteration of particular gene and gene networks that contribute to the pathophysiology of particular tumor. Some of the

Table 1 Common Histone-Modifying Enzymes Amplified/Overexpressed/Mutated in Cancer

\begin{tabular}{|c|c|c|c|}
\hline Gene & Cancer type & Alteration & References \\
\hline$E Z H 2$ & $\begin{array}{l}\text { Prostate, breast, bladder, ovarian, lung, liver, } \\
\text { brain, kidney, gastric, esophageal, and } \\
\text { pancreatic cancer and melanoma }\end{array}$ & Amplified/overexpressed & 36 \\
\hline$M L L 4$ & Breast & Amplification & 37 \\
\hline SETDB1 & Melanoma, lung, prostate & Overexpressed/amplification & $35,38,39$ \\
\hline EHMT1 & Esophageal & Overexpressed & 40 \\
\hline EHMT2 & Bladder, breast, cervical, lung, and others & Overexpressed & 41 \\
\hline$K D M 1 A$ & Prostate, bladder & Overexpression & 42 \\
\hline KDM6A & Acute myelogenous leukemia, bladder & Down-regulation & 17 \\
\hline PCAF & Epithelial & Missense mutation & 43 \\
\hline P300 & Gastric, colon, breast & Biallelic and stop codon mutations & 44 \\
\hline$H D A C 1$ & Gastric, prostate & Overexpression & 45,46 \\
\hline$A U R K B$ & Colorectal & Overexpression & 47 \\
\hline$B \cup B 1$ & Gastric & Overexpression & 48 \\
\hline RING2 and UBCH6 & Role in cancer yet to be confirmed & & 49 \\
\hline
\end{tabular}


high-throughput technologies used in the area of diagnosis include gene expression profiling, array-based comparative genomic hybridization, single-nucleotide polymorphism array, and NGS. These techniques offer remarkable insights into altered molecular network in cancer and tumor biology.

The advances made in NGS, also known as massively parallel sequencing method, marked another significant step forward in personalized cancer genomics and revealed multiple molecular aberrations that drive cancer. ${ }^{57} \mathrm{Re}-$ searchers have used different sequencing platforms to identify copy number variations, somatic mutations, and other aberrations in cancer, which lead to the identification of key pathways that are altered in cancer.

The sensitivity, speed, and low cost per sample make this technology a highly attractive tool in personalized medicine and precision medicine applications. Studies have shown the significance of NGS in personalized medicine and clinical management of cancer. ${ }^{58}$ The NGS technology has been widely used for de novo genome sequencing, transcriptome sequencing, and epigenomics, in both research and clinical laboratories. ${ }^{59}$ The human cancer research has been benefited tremendously by many of these high-throughput technologies and led to numerous discoveries, including identification of mutations and gene fusions, some of which are targetable. ${ }^{60}$ Notable examples of its clinical use are efficient detection of either inherited or somatic mutations and, single-base substitutions, copy-number variations, and focal amplifications in cancer-related genes, ${ }^{61}$ and prenatal testing chromosomal aneuploidy in fetal DNA. ${ }^{62}$ Apart from identifying multiple genomic alterations in cancer, the highthroughput technologies helped unravel genomic signatures that are shared across tumor types, providing a basis for classification of cancer on the basis of molecular aberrations. ${ }^{63}$ Tumor classification on the basis of recurrent genetic and epigenetic alterations that converge on unique pathways in different tumors can potentially suggest common treatment options. Availability of these technologies and the decreasing cost is allowing the progress in the area of precision medicine and personalized treatment of cancer patients. ${ }^{58}$

\section{Noncoding RNAs in Cancer}

Gene expression is also known to be regulated by noncoding small RNA molecules. Changes in noncoding RNAs, including miRNAs, are common events in cancer that are now being investigated extensively. miRNAs are small single-stranded RNA molecules that are shown to be dysregulated in cancer and play a diverse role in cancer progression and metastasis. ${ }^{64}$ Expression profiling of miRNAs has shown both overexpression and down-regulation of multiple miRNAs that target protein-coding genes. miRNAs are present within intronic genomic DNA or within the exons of protein-coding genes. ${ }^{65}$ Epigenetic alterations, such as DNA methylation and histone modification, are known to alter miRNA expression. ${ }^{66}$ Tumor suppressor miRNA, MIR127, is silenced in bladder cancer and this silencing can be rescued by DNA demethylation and histone deacetylase inhibition, suggesting miRNAs as potential targets for epigenetic therapy. ${ }^{67}$ miRNAs can serve as either tumor suppressors or oncogenes on the basis of their role in cancer progression and the target genes of specific miRNAs. miR-101, which acts as a tumor suppressor, targets EZH2, and is found to be downregulated in prostate ${ }^{68}$ and bladder cancers. ${ }^{69}$ Conversely, miR-155 acts as an oncogene by affecting the recombination process via cytidine deaminase, ${ }^{70}$ and is up-regulated in breast and lung cancers. Oncomir MIR21 is overexpressed in breast cancer, ${ }^{71}$ glioblastoma, ${ }^{72}$ prostate cancer, ${ }^{73}$ and others. miR$10 \mathrm{~b}$ is known to regulate breast cancer metastasis. ${ }^{74}$ These studies and others suggest the wide range of roles played by miRNAs in regulating cancer initiation and progression.

NGS of tumors led to the identification of large number of long noncoding RNAs (lncRNAs) and shown to be dysregulated in common malignancies. Studies using large number of tumors, normal tissues, and cell lines discovered up to 60,000 lncRNA genes. ${ }^{75}$ The mechanisms through which IncRNAs contribute to the cancer development are diverse. Investigations suggested that IncRNAs guide chromatinmodifying complexes to effect epigenetic changes. Approximately $38 \%$ of them bind to the polycomb repressive complex 2 or the chromatin-modifying proteins RCOR1 (COREST) and KDM5C (SMCX), and others bind to trithorax chromatinactivating complexes and/or activated chromatin. ${ }^{76}$ Previous studies have shown that the well-characterized lncRNAs HOTAIR, XIST, CDKN2B-AS1, and KCNQ1OT1 are able to recruit epigenetic modifiers to specific loci to reprogram the chromatin state. ${ }^{76}$ PCAT1 has been identified as a prostatespecific lncRNA that has been implicated in disease progression. ${ }^{77}$ Later, another long noncoding RNA SCHLAP1 (second chromosome locus associated with prostate-1; also called LINC00913) expression was reported to independently predict lethal prostate cancer. ${ }^{78}$ More importantly, it blocks the localization and regulatory functions of SWI/SNF complex in prostate cancer. ${ }^{79}$ Many earlier studies have demonstrated that IncRNAs, HOTTIP, TP53COR1/Linc-p21, MALAT1, HOTAIR, PCAT1, among others, are under the regulation of miRNAs to reduce their stability. ${ }^{80,81}$

\section{Clinical Implementation of Genomic and Epigenomic Variations in Cancer}

Many of the genomic events that occur during cancer progression can be used in clinical evaluation of disease. Plasma is a good source for early cancer detection that contains DNA fragments shed by apoptotic or necrotic normal and cancer cells. There are reports of TP53 mutations in plasma DNA in patients with cancers of the colon, lung, pancreas, and liver. ${ }^{82}$ Moreover, tumor-derived DNA with TP53 mutations were observed in the plasma of advanced stages of ovarian cancer patients. ${ }^{83}$ In addition, a specific TP53 mutation (at codon 249) has been detected in 
the plasma of non-cancer subjects exposed to high rates to aflatoxin and were chronic carriers of hepatitis B virus, up to 5 years ahead of the development of hepatocellular carcinoma. ${ }^{84}$ It was shown that the presence of TP53 and/or $K R A S$ mutations in plasma DNA of healthy subjects was predictive of the risk of bladder cancer in a large prospective study. ${ }^{85}$ Several studies have investigated the prognostic value of TP53 mutation status for tumor response to treatment and patient outcome in various cancers. It was observed that the presence of a mutation (eg, the DNAbinding domain of TP53) is associated with bad prognosis. Similarly, a detailed assessment of the prognostic significance of TP53 mutations in a large breast cancer patient cohort was reported. ${ }^{86}$ This study further showed that TP53 mutation was a predictor of poor overall survival independently of the currently available prognostic factors, such as tumor size, node status, and estrogen and progesterone receptor contents.

Activating mutations in the tyrosine kinase domain of $E G F R$ are predominantly present in lung adenocarcinomas of nonsmokers, and are mutually exclusive with KRAS mutational status. ${ }^{87}$ Thus, mutation in EGFR may constitute an interesting biomarker of a lung cancer different from the one initiated by exposure to tobacco smoke. Aberrant DNA hypermethylation of some key genes, like estrogen receptor $(E R / E S R 1)-\alpha$ and progesterone receptor $(P G R)$, in development of estrogen receptor- and progesterone receptornegative breast cancer and might be useful as prognostic or diagnostic markers. Similarly, aberrant DNA hypermethylation of genes paired like homeodomain transcription factor-2 (PITX2) and ras association (RalGDS/AF-6) domain family member 1 (RASSF1A) are considered as potential diagnostic markers of breast cancer. ${ }^{88}$ Thus, the DNA methylation status of such genes might show value as predictive biomarkers. Global reduction of monoacetylated lysine 16 of histone $\mathrm{H} 4$ (H4K16) is the most common event in cancer. ${ }^{89}$ The loss or low levels of H4K16 acetylation was suggested as an early event in breast cancer. Interestingly, miRNA profiling displayed distinct patterns that may classify cancers according to the developmental lineage and differentiation status, contributing miRNAs as useful tools in cancer diagnostics and prognosis. ${ }^{82}$

Prostate cancer antigen (PCA3) is one of the most sensitive and is highly prostate cancer-specific biomarker. It has been shown to be overexpressed in $>90 \%$ of prostate cancer patients. Moreover, $P C A 3$ has been extensively studied as a urine-based prostate cancer biomarker. ${ }^{90}$ The TMPRSS2:ERG fusion is studied as a biomarker detected in urine (alone or in conjunction with $P C A 3$ ) which is one of the noninvasive tests in prostate cancer. ${ }^{90}$

\section{Cancer and Immune System}

Epigenetic alteration in cancer cells affects the expression of immune genes, which potently influence the ability of immune system to suppress tumors. DNA methylation is involved in several immune-related responses, including T-cell maturation and differentiation, Th1/Th2 polarization, and TcR rearrangements. The antitumor effect of CD8 T cell and interferon- $\gamma$ antitumor response could also be compromised by epigenetic alteration. ${ }^{91}$ Moreover, many oncogenes related to p53 pathway, DNA repair, or cell cycle are hypermethylated in cancers, potently leading to changes in immune responses. ${ }^{12}$

Many reports support the notion that immune system plays a critical role in cancer development. Studies have highlighted the double-edged sword nature of immune system in cancer. On one hand, immune system protects the body from cancer, but on the other hand, can shape the tumor immunogenicity. During initial stage of cancer development, immunosurveillance mechanism is intact wherein immune system is able to attack tumors; however, as cancer cells proliferate, the capacity of tumor cells in escaping immunosurveillance overwhelms, leading to oncogenesis. $^{92}$

During the course of tumor development, tumors are known to subvert the normal immune regulation in such a way that it benefits tumor survival. In addition, loss of tumor antigens, sensitivity to complement, $\mathrm{T}$ cell lysis, or natural killer cells could offer escape from immune regulation to tumor cells. ${ }^{93}$

The advent of immune checkpoint-blockade therapies that cause T-cell activation has imparted attention in the field of cancer immunology. ${ }^{94}$ These therapies suppress the activation of immune inhibitory pathways. Cytotoxic T lymphocyte-associated antigen 4 (CTLA4) was the first immune checkpoint receptor to be clinically targeted. After T-cell activation, CTLA4 is normally up-regulated on cell membrane and it functions to down-regulate $\mathrm{T}$-cell function through other mechanisms. Thereby, it plays a crucial role in normal immunological homeostasis, as it was demonstrated that mice deficient in CTLA4 die from fatal lymphoproliferation. ${ }^{95}$ As it is a negative regulator of immunity, many researchers targeted CTLA4 with monoclonal antibodies to achieve antitumor immunity. ${ }^{95}$ Furthermore, to target this molecule, an antibody ipilimumab (Bristol-Myers Squibb, Princeton, NJ) was successful in improving overall survival in advanced melanoma patients and benefits in other malignancies, like pancreatic, prostate, and non-small-cell lung cancers. ${ }^{95}$ Another blocking antibody to CTLA4, tremelimumab (MedImmune/ AstraZeneca, Wilmington, DE), has shown responses in mesothelioma patients. ${ }^{95}$

The successful targeting of CTLA4 helped in conducting clinical approaches to target other immunological checkpoints, namely programmed death-1 PD1 (PDCD1)/PDL1 and programmed death-ligand 1 CD274 (PDL1). Many cancers and immune cells express CD274, which plays a crucial role by inhibiting the cancer immunity cycle through binding PDCD1. ${ }^{96}$ Tumoral CD274 expression status has been demonstrated to be prognostic in multiple tumor types, 
including non-small-cell lung cancer, melanoma, and renal cell carcinoma. In addition, tumoral CD274 expression correlates closely with response to anti-PDCD1 antibodies. ${ }^{97}$ Monoclonal antibodies that disrupt the PDCD1/ CD274 interaction have demonstrated favorable activity in renal cell carcinoma as single and in combinational therapy. ${ }^{98}$ Several PD1 (PDCD1) [nivolumab (Bristol-Myers Squibb); pembrolizumab (Merck, Whitehouse Station, NJ); pidilizumab (CureTech, Yavne, Israel)] and CD274 (PDL1) [MPDL3280A (Genentech, South San Francisco, CA); MEDI4736 (MedImmune/AstraZeneca); BMS-936559 (Bristol-Myers Squibb); MSB0010718C (EMD Serono, Rockland, MA)] antibodies are in clinical development. ${ }^{95,99}$ Both nivolumab and pembrolizumab have shown encouraging results with minimal toxicity in large phase I studies involving patients with non-small-cell lung cancer, renal cell carcinoma, advanced melanoma, and other solid tumors. ${ }^{95}$ Recently, the FDA approved pembrolizumab for patients with melanoma previously treated with ipilimumab. ${ }^{95}$ On other hand, pidilizumab, as a single agent and in combination regimens with rituximab, has been clinically tested in hematological malignancies. ${ }^{95}$ Similarly, the first CD274/PDL1 antibody BMS956559 showed responses in patients with a variety of solid tumors. ${ }^{100}$ Other immunotherapeutics, like MPDL3280A, MEDI4736, and MSB0010718C, have also shown promising results in early-phase clinical trials in several malignancies, including tumor types such as bladder cancer, head and neck cancer, and gastrointestinal tract malignancies. ${ }^{95}$ Metastatic melanoma immune checkpoint inhibitors, such as anti-CTLA4 antibody and anti-CD274/PDCD1, along with radiation are effective in tumor regression. ${ }^{101}$

\section{Therapeutic Targeting of Epigenetic Modifiers in Cancer}

The genome-epigenome interaction is crucially involved in the cancer biology. As discussed in Common Genomic and Epigenomic Alterations in Cancer, deregulation of epigenetic machinery is a critical lesion in cancer. Targeting these epigenetic modifiers constitutes the epigenetic therapy. Epigenetic therapy can be achieved by the development of small-molecule inhibitors, which is crucial for evolution of new therapeutic approaches through the use of both natural and synthetic molecules. Pharmacological inhibition of EZH2 was recently shown as a promising approach to treat cancer with activating mutation in $E Z H 2$ or in tumors with inactivating mutation in ARIDIA. ${ }^{51}$ Similarly, it was demonstrated that SMARCA4/BRG1 loss-of-function mutant tumors showed increased Topo II inhibitor sensitivity under EZH2 inhibition background. $^{51}$

Understanding the mechanism of action of chromatin components and their role in gene activation and silencing process can enable developmental strategy to target these events. Because epigenetic changes are reversible, DNA methylation inhibitors such as 5-azacytidine and 5-aza-2'deoxycytidine have been used in the treatment of leukemia and myelodysplastic syndrome. ${ }^{12}$ In addition, epigenetic therapy with the use of transcription factors that target specific gene promoters, such as the zinc finger protein targeting sequences in SERPINB5/MASPIN promoter has been shown to inhibit tumor growth in vitro. ${ }^{102}$ DNA methylation techniques, including detection of $\mathrm{CpG}$-island or specific genes' hypermethylation can be used in early

Table 2 Epigenetic Inhibitors That Are Approved or in Clinical Development

\begin{tabular}{|c|c|c|c|}
\hline Name & Target & Approved/in clinical development* & References/identifier number $^{\dagger}$ \\
\hline Azacitidine and decitabine & DNMT inhibitors & Myelodysplastic syndrome & 105 \\
\hline $\begin{array}{l}\text { Vorinostat (Merck) and } \\
\text { romidepsin (Celgene) }\end{array}$ & Pan-HDAC inhibitor & Cutaneous T-cell lymphoma & 106,107 \\
\hline Ruxolitinib & JAK1/2 inhibitors & Intermediate or high-risk myelofibrosis & 108 \\
\hline Entinostat & $\begin{array}{l}\text { Class I HDAC } \\
\text { inhibitor }\end{array}$ & $\begin{array}{l}\text { Phase III in breast cancer; phase I and II in Hodgkin } \\
\text { lymphoma and kidney cancer* }\end{array}$ & $\begin{array}{l}\text { NCT00866333, NCT01038778, } \\
\text { NCT01349959 }\end{array}$ \\
\hline Panobinostat (Novartis) & Pan-HDAC inhibitor & $\begin{array}{l}\text { Phase III in Hodgkin lymphoma and multiple myeloma; } \\
\text { phase II/III in cutaneous T-cell lymphoma* }\end{array}$ & $\begin{array}{l}\text { NCT01034163, NCT01023308, } \\
\text { NCT00425555 }\end{array}$ \\
\hline CI-994 (CI-994) & Pan-HDAC inhibitor & $\begin{array}{l}\text { Phase II completed in advanced myeloma*; phase III } \\
\text { currently in non-small-cell lung cancer* }\end{array}$ & NCT00005624 $4^{107}$ \\
\hline Phenelzine sulfate & HDM inhibitor & Phase II in prostate cancer* & NCT01253642 \\
\hline Epigallocatechin gallate & DNMT inhibitor & Phase II in multiple myeloma* & NCT01589887 \\
\hline EPZ-6438 & $\mathrm{EZH} 2$ & $\begin{array}{l}\text { Phase I/II clinical trials for solid tumors and } \\
\text { hematological malignancies* }\end{array}$ & NCT01897571 \\
\hline EPZ-5676 & D0T1L inhibitor & $\begin{array}{l}\text { Phase I in relapsed/refractory adult and pediatric } \\
\text { MLL-rearranged leukemias* }\end{array}$ & NCT02141828, NCT01684150 \\
\hline GSK2879552 & LSD1 inhibitor & Phase I for acute myeloid leukemia* & NCT02177812 \\
\hline CPI-0610 and 0TX015 & BET inhibitors & Phase $\mathrm{I}$ in refractory acute leukemias and $\mathrm{HM}^{*}$ & NCT02158858, NCT01713582 \\
\hline
\end{tabular}

*Denotes the inhibitors that are in clinical development.

${ }^{\dagger}$ Identifier numbers are for studies found on the Clinical Trials website (https.clinicaltrials.gov).

DNMT, DNA methyltransferase; HDAC, histone deacetylase; HDM, histone demethylase; HM, hematologic malignancies; JAK, Janus kinase; MLL, mixedlineage leukemia. 
diagnosis of patients with prostate cancer and even prognosis for patients with glioma. ${ }^{103,104}$ Several small-molecule inhibitors have already been developed against chromatin regulators (Table 2). Several phase II and III trials are also under way with these agents in a variety of cancer types. The FDA granted approval for three inhibitors targeting histone deacetylases, DNA methyltransferases, and Janus kinase 2. A pan-histone deacetylasis inhibitor vorinostat and class I-specific histone deacetylase inhibitor romidepsin has been granted FDA approval on the basis of preclinical and clinical data for clinical use in patients with cutaneous T-cell lymphoma. The broad histone deacetylase inhibitors panobinostat and belinostat, and the class I inhibitor entinostat are in advanced stages of clinical development. ${ }^{106}$ Studies indicated that three naturally occurring small molecules (anacardic acid, curcumin, and garcinol) have HAT inhibitory activity. ${ }^{109}$ Among which the active ingredient in turmeric, curcumin, is in phase II trials in advanced breast (NCT01740323), pancreatic (NCT00094445), and colorectal cancer (NCT01490996) (identifier numbers for studies on https.clinicaltrials.gov). In addition, the inhibitors to histone methyl transferase EZH2, such as CPI-1205, EPZ-6438, and GSK2816126, are in various stages of development and trials. Lysine (K)-specific demethylase 1A LSD1/KDM1A inhibitor phenelzine sulfate is in phase II trials in combination with docetaxel in prostate cancer (NCT01253642). The kinases that phosphorylate histones are known to play a role in cancer development, although it is not fully understood except Janus kinase 2. The FDA approved ruxolitinib (Janus kinase $1 / 2$ inhibitor) for the treatment of intermediate or highrisk myelofibrosis.

Novel pharmacological strategies have been developed to target the interaction of histones and the bromodomaincontaining BET reader proteins. ${ }^{110}$ Some of the inhibitors in clinical trials include OTX015 for acute leukemia and other hematological malignancies (NCT01713582), CPI-0610 (NCT01949883) against progressive lymphoma, and GSK525762 (NCT01587703) against solid tumors and hematological malignancies.

\section{Future Perspective}

Advances made during the past decade in early detection of cancer have improved patient health tremendously. Many of the novel target discoveries led to therapeutic inhibition. Advances are also being made in nanomedicine that involve application of nanotechnology for treatment, diagnosis, and monitoring of biological systems. Nanomedical research deals with the precise delivery and targeting of therapeutic agents. Nano-oncology is an area of interdisciplinary research that attempts to integrate cancer biology, chemistry, engineering, and medicine to attain advances in detection and treatment of cancer.

Detection, isolation, and characterization of circulating tumor cells (CTCs) have also opened up new avenues in noninvasive detection in cancer diagnosis and treatment. Detection of CTCs serves as a noninvasive method of detecting cancer in patients. CTCs are rare tumor cells (approximately 1 to 100 CTCs per $10^{9}$ blood cells) shed from primary and metastatic tumor sites. ${ }^{111}$ The FDA approved CellSearch (Veridex, NJ) system has been used for CTC detection in metastatic breast, colorectal, and prostate cancer. ${ }^{112}$ In addition, integrated microfluidic system specifically designed for isolation, purification, and single-cell secretomic profiling of CTCs from whole blood. Guardant360 is a noninvasive platform that uses cell-free DNA for detection of panel of genes that are generally mutated in cancer. ${ }^{113}$ Another advance that is being made is related to cellular barcoding, ${ }^{114}$ and this technology has been used to interrogate complex tissues and cellular libraries at single-cell resolution. Here, the basic principle involves tagging the cells of interest with unique heritable identifiers or barcodes; a noncoding stretches of DNA and is delivered by means of lenti or retroviral vectors. Barcoding of cells using cell-surface expression of programmable zincfinger DNA-binding domains (surface zinc fingers) has been reported. It was shown that surface zinc fingers enable sequence-specific labeling of living cells by double-stranded DNA and a sequence-specific labeling approach to image more than three cell types was also developed. ${ }^{115}$ These samples then can be used in high-throughput technologies. The NGS allows massively parallel processing of samples by using several primers for various samples, which are then pooled for sequencing. This technology allows determining the progenitor fates at the single-cell level by comparing the shared and distinct barcodes between cell types. Hundreds of single-cell assays can be performed simultaneously using this technology.

Progress in functional genomics and genome-editing technologies are also significantly aiding in understanding the biology of cancer and therapeutic targeting. RNA interference has helped in understanding the functions of many genes and gene interaction networks. Genome editing with engineered nucleases is a genetic engineering method in which fragments of DNA are inserted, replaced, or removed from specific genomic sequences in living cells, using artificially engineered nucleases, for the purpose of determining, changing, or expanding their function(s). The genome editing procedure needs sequence-specific designer nucleases and donor DNA constructs. Some of the designer nucleases are clustered as regularly interspaced short palindromic repeats/Cas $9,{ }^{116}$ transcription activator-like effector nucleases, and zinc finger nucleases. ${ }^{117}$ These technologies can be used to generate gene knockouts or gene knockins when applied alone or in combination with donor DNA templates, respectively.

Significant advances are being made in cancer drug discovery effort as well. Development of patient-derived xenograft (PDX) models are extensively used in cancer biology, and they offer a tool for drug discovery and personalized medicine. ${ }^{118}$ PDX models are based on the 
transfer of primary tumors directly from the patient into an immunodeficient mouse. Key assumptions of developing PDX models for cancer research has been that they resemble the original tumor and are known to maintain across passages. ${ }^{119}$ It has been shown that even after several passages, PDXs retain their originality from genomics, proteomics, and at transcriptomics level and show similar observations as that of clinics. ${ }^{120}$ However, one important limitation of PDX models is the substitution of human cancer-associated stromal components by murine elements and lack of a functional immune system. ${ }^{121}$ Further investigations are needed to understand how the differences in the immune system affect drug response and predictability for therapeutic efficacy in human tumors. There is a great interest of reconstituting of a human immune system in the mouse. These models are of interest to study immune therapeutics. Artificial PDX models are also being generated by implanting malignant tissues in threedimensional culture systems and bioreactors. ${ }^{122}$ These systems have the potential use in screening of small molecules targeting oncogenes. Many of the above-mentioned technologies will have the potential to be transformative in clinical cancer care and treatment.

\section{Conclusions}

Advances in high-throughput technologies enabled significant progress in understanding the molecular alterations and biology of cancer. Continuing progress in functional genomics, systems biology, and bioinformatics will have the potential for using the accumulating data effectively in investigating pathway alteration during disease initiation and progression as well as in identifying effective therapeutic targets. Predicting development of resistance to therapy and identification of secondary targets by network analysis will aid in developing effective therapeutic strategies. Live cell imaging, dynamic analysis of molecular interactions, circulating tumor cell analysis, and nanotechnology are transformative in cancer research and in precision medicine. Although there has been tremendous progress in genomic and epigenetic research, exciting possibilities still remain. With the availability of large-scale genomic and epigenomic data sets, identifying the additional tumor driving aberrations from the passenger genetic and epigenetic events becomes important to understand and treat cancer effectively. Identification of synthetic lethality will enable targeting tumors with some of the available anticancer molecules. Understanding the development of resistance to therapy is critical in advancing effective combination therapy. Investigating the isolated but tumor driving aberration is critical for diagnosis and treatment of small subset of cancer patients, allowing personalized treatment options. Analysis of vast amount of genomic DNA that is considered as junk DNA will also be of significance to identify changes in regulatory and unexplored regions in the tumor genome. The interplay between genetic and epigenetic events needs further investigation to better understand the events leading to cancer initiation, progression, and therapy resistance.

\section{Acknowledgments}

Because of space limitations, we could not cite many of the excellent research articles and reviews in the present review in this exciting and vast area of research. We sincerely apologize to authors whose work has not been cited.

\section{References}

1. Siegel RL, Miller KD, Jemal A: Cancer statistics, 2016. CA Cancer J Clin 2016, 66:7-30

2. Stratton MR, Campbell PJ, Futreal PA: The cancer genome. Nature 2009, 458:719-724

3. Talbot SJ, Crawford DH: Viruses and tumours: an update. Eur J Cancer 2004, 40:1998-2005

4. Olivier M, Hussain SP, Caron de Fromentel C, Hainaut P, Harris CC TP53 mutation spectra and load: a tool for generating hypotheses on the etiology of cancer. IARC Sci Publ 2004:247-270

5. Greenman C, Stephens P, Smith R, Dalgliesh GL, Hunter C, Bignell G, et al: Patterns of somatic mutation in human cancer genomes. Nature 2007, 446:153-158

6. Miller DG: On the nature of susceptibility to cancer: the presidential address. Cancer 1980, 46:1307-1318

7. Dawson MA, Kouzarides T: Cancer epigenetics: from mechanism to therapy. Cell 2012, 150:12-27

8. Sharma S, Kelly TK, Jones PA: Epigenetics in cancer. Carcinogenesis 2010, 31:27-36

9. Fullgrabe J, Kavanagh E, Joseph B: Histone onco-modifications. Oncogene 2011, 30:3391-3403

10. Bannister AJ, Kouzarides T: Regulation of chromatin by histone modifications. Cell Res 2011, 21:381-395

11. Rossetto D, Avvakumov N, Cote J: Histone phosphorylation: a chromatin modification involved in diverse nuclear events. Epigenetics 2012, 7:1098-1108

12. Esteller M: Epigenetics in cancer. N Engl J Med 2008, 358 $1148-1159$

13. Jones PA, Baylin SB: The epigenomics of cancer. Cell 2007, 128: 683-692

14. Gonzalgo ML, Nakayama M, Lee SM, De Marzo AM, Nelson WG: Detection of GSTP1 methylation in prostatic secretions using combinatorial MSP analysis. Urology 2004, 63:414-418

15. Jenuwein T, Allis CD: Translating the histone code. Science 2001, 293:1074-1080

16. Baylin SB, Ohm JE: Epigenetic gene silencing in cancer: a mechanism for early oncogenic pathway addiction? Nat Rev Cancer 2006, 6:107-116

17. van Haaften G, Dalgliesh GL, Davies H, Chen L, Bignell G, Greenman C, et al: Somatic mutations of the histone H3K27 demethylase gene UTX in human cancer. Nat Genet 2009, 41:521-523

18. Morin RD, Mendez-Lago M, Mungall AJ, Goya R, Mungall KL, Corbett RD, et al: Frequent mutation of histone-modifying genes in non-Hodgkin lymphoma. Nature 2011, 476:298-303

19. Morin RD, Johnson NA, Severson TM, Mungall AJ, An J, Goya R, et al: Somatic mutations altering EZH2 (Tyr641) in follicular and diffuse large B-cell lymphomas of germinal-center origin. Nat Genet 2010, 42:181-185

20. Xi R, Hadjipanayis AG, Luquette LJ, Kim TM, Lee E, Zhang J, Johnson MD, Muzny DM, Wheeler DA, Gibbs RA, Kucherlapati R, Park PJ: Copy number variation detection in whole-genome 
sequencing data using the Bayesian information criterion. Proc Natl Acad Sci U S A 2011, 108:E1128-E1136

21. Mertens F, Johansson B, Fioretos T, Mitelman F: The emerging complexity of gene fusions in cancer. Nat Rev Cancer 2015, 15 : $371-381$

22. Tomlins SA, Rhodes DR, Perner S, Dhanasekaran SM, Mehra R, Sun XW, Varambally S, Cao X, Tchinda J, Kuefer R, Lee C, Montie JE, Shah RB, Pienta KJ, Rubin MA, Chinnaiyan AM: Recurrent fusion of TMPRSS2 and ETS transcription factor genes in prostate cancer. Science 2005, 310:644-648

23. Kumar-Sinha C, Tomlins SA, Chinnaiyan AM: Recurrent gene fusions in prostate cancer. Nat Rev Cancer 2008, 8:497-511

24. Edgren H, Murumagi A, Kangaspeska S, Nicorici D, Hongisto V, Kleivi K, Rye IH, Nyberg S, Wolf M, Borresen-Dale AL, Kallioniemi O: Identification of fusion genes in breast cancer by paired-end RNA-sequencing. Genome Biol 2011, 12:R6

25. Palanisamy N, Ateeq B, Kalyana-Sundaram S, Pflueger D, Ramnarayanan K, Shankar S, Han B, Cao Q, Cao X, Suleman K, Kumar-Sinha C, Dhanasekaran SM, Chen YB, Esgueva R, Banerjee S, LaFargue CJ, Siddiqui J, Demichelis F, Moeller P, Bismar TA, Kuefer R, Fullen DR, Johnson TM, Greenson JK, Giordano TJ, Tan P, Tomlins SA, Varambally S, Rubin MA, Maher CA, Chinnaiyan AM: Rearrangements of the RAF kinase pathway in prostate cancer, gastric cancer and melanoma. Nat Med 2010, 16:793-798

26. Soda M, Choi YL, Enomoto M, Takada S, Yamashita Y, Ishikawa S, Fujiwara S, Watanabe H, Kurashina K, Hatanaka H, Bando M, Ohno S, Ishikawa Y, Aburatani H, Niki T, Sohara Y, Sugiyama Y, Mano H: Identification of the transforming EML4-ALK fusion gene in non-small-cell lung cancer. Nature 2007, 448:561-566

27. Delhommeau F, Dupont S, Della Valle V, James C, Trannoy S, Masse A, Kosmider O, Le Couedic JP, Robert F, Alberdi A, Lecluse Y, Plo I, Dreyfus FJ, Marzac C, Casadevall N, Lacombe C, Romana SP, Dessen P, Soulier J, Viguie F, Fontenay M, Vainchenker W, Bernard OA: Mutation in TET2 in myeloid cancers. N Engl J Med 2009, 360:2289-2301

28. Figueroa ME, Abdel-Wahab O, Lu C, Ward PS, Patel J, Shih A, Li Y, Bhagwat N, Vasanthakumar A, Fernandez HF, Tallman MS, Sun Z, Wolniak K, Peeters JK, Liu W, Choe SE, Fantin VR, Paietta E, Lowenberg B, Licht JD, Godley LA, Delwel R, Valk PJ, Thompson CB, Levine RL, Melnick A: Leukemic IDH1 and IDH2 mutations result in a hypermethylation phenotype, disrupt TET2 function, and impair hematopoietic differentiation. Cancer Cell 2010, 18:553-567

29. Wilson AS, Power BE, Molloy PL: DNA hypomethylation and human diseases. Biochim Biophys Acta 2007, 1775:138-162

30. Lin JC, Jeong S, Liang G, Takai D, Fatemi M, Tsai YC, Egger G, Gal-Yam EN, Jones PA: Role of nucleosomal occupancy in the epigenetic silencing of the MLH1 CpG island. Cancer Cell 2007, 12: 432-444

31. Issa JP: CpG island methylator phenotype in cancer. Nat Rev Cancer 2004, 4:988-993

32. Kleer CG, Cao Q, Varambally S, Shen R, Ota I, Tomlins SA, Ghosh D, Sewalt RG, Otte AP, Hayes DF, Sabel MS, Livant D, Weiss SJ, Rubin MA, Chinnaiyan AM: EZH2 is a marker of aggressive breast cancer and promotes neoplastic transformation of breast epithelial cells. Proc Natl Acad Sci U S A 2003, 100: 11606-11611

33. Varambally S, Dhanasekaran SM, Zhou M, Barrette TR, KumarSinha C, Sanda MG, Ghosh D, Pienta KJ, Sewalt RG, Otte AP, Rubin MA, Chinnaiyan AM: The polycomb group protein EZH2 is involved in progression of prostate cancer. Nature 2002, 419: 624-629

34. Asangani IA, Ateeq B, Cao Q, Dodson L, Pandhi M, Kunju LP, Mehra R, Lonigro RJ, Siddiqui J, Palanisamy N, Wu YM, Cao X, Kim JH, Zhao M, Qin ZS, Iyer MK, Maher CA, Kumar-Sinha C, Varambally S, Chinnaiyan AM: Characterization of the EZH2-
MMSET histone methyltransferase regulatory axis in cancer. Mol Cell 2013, 49:80-93

35. Ceol CJ, Houvras Y, Jane-Valbuena J, Bilodeau S, Orlando DA, Battisti V, Fritsch L, Lin WM, Hollmann TJ, Ferre F, Bourque C, Burke CJ, Turner L, Uong A, Johnson LA, Beroukhim R, Mermel CH, Loda M, Ait-Si-Ali S, Garraway LA, Young RA, Zon LI: The histone methyltransferase SETDB1 is recurrently amplified in melanoma and accelerates its onset. Nature 2011, 471:513-517

36. Yamaguchi H, Hung MC: Regulation and role of EZH2 in cancer. Cancer Res Treat 2014, 46:209-222

37. Kim JH, Sharma A, Dhar SS, Lee SH, Gu B, Chan CH, Lin HK, Lee MG: UTX and MLL4 coordinately regulate transcriptional programs for cell proliferation and invasiveness in breast cancer cells. Cancer Res 2014, 74:1705-1717

38. Rodriguez-Paredes M, Martinez de Paz A, Simo-Riudalbas L, Sayols S, Moutinho C, Moran S, Villanueva A, Vazquez-Cedeira M, Lazo PA, Carneiro F, Moura CS, Vieira J, Teixeira MR, Esteller M: Gene amplification of the histone methyltransferase SETDB1 contributes to human lung tumorigenesis. Oncogene 2014, 33:2807-2813

39. Sun Y, Wei M, Ren SC, Chen R, Xu WD, Wang FB, Lu J, Shen J, Yu YW, Hou JG, Xu CL, Huang JT, Sun YH: Histone methyltransferase SETDB1 is required for prostate cancer cell proliferation, migration and invasion. Asian J Androl 2014, 16:319-324

40. Guan X, Zhong X, Men W, Gong S, Zhang L, Han Y: Analysis of EHMT1 expression and its correlations with clinical significance in esophageal squamous cell cancer. Mol Clin Oncol 2014, 2:76-80

41. Cho HS, Kelly JD, Hayami S, Toyokawa G, Takawa M, Yoshimatsu M, Tsunoda T, Field HI, Neal DE, Ponder BA, Nakamura Y, Hamamoto R: Enhanced expression of EHMT2 is involved in the proliferation of cancer cells through negative regulation of SIAH1. Neoplasia 2011, 13:676-684

42. Hoffmann I, Roatsch M, Schmitt ML, Carlino L, Pippel M, Sippl W, Jung M: The role of histone demethylases in cancer therapy. Mol Oncol 2012, 6:683-703

43. Ozdag H, Batley SJ, Forsti A, Iyer NG, Daigo Y, Boutell J, Arends MJ, Ponder BA, Kouzarides T, Caldas C: Mutation analysis of $\mathrm{CBP}$ and PCAF reveals rare inactivating mutations in cancer cell lines but not in primary tumours. Br J Cancer 2002, 87:1162-1165

44. Santos-Rosa H, Caldas C: Chromatin modifier enzymes, the histone code and cancer. Eur J Cancer 2005, 41:2381-2402

45. Choi JH, Kwon HJ, Yoon BI, Kim JH, Han SU, Joo HJ, Kim DY: Expression profile of histone deacetylase 1 in gastric cancer tissues. Jpn J Cancer Res 2001, 92:1300-1304

46. Halkidou K, Gaughan L, Cook S, Leung HY, Neal DE, Robson CN: Upregulation and nuclear recruitment of HDAC1 in hormone refractory prostate cancer. Prostate 2004, 59:177-189

47. Fu J, Bian M, Jiang Q, Zhang C: Roles of Aurora kinases in mitosis and tumorigenesis. Mol Cancer Res 2007, 5:1-10

48. Grabsch H, Takeno S, Parsons WJ, Pomjanski N, Boecking A, Gabbert HE, Mueller W: Overexpression of the mitotic checkpoint genes BUB1, BUBR1, and BUB3 in gastric cancer: association with tumour cell proliferation. J Pathol 2003, 200:16-22

49. Wang H, Wang L, Erdjument-Bromage H, Vidal M, Tempst P, Jones RS, Zhang Y: Role of histone H2A ubiquitination in Polycomb silencing. Nature 2004, 431:873-878

50. Cao R, Wang L, Wang H, Xia L, Erdjument-Bromage H, Tempst P, Jones RS, Zhang Y: Role of histone H3 lysine 27 methylation in polycomb-group silencing. Science 2002, 298:1039-1043

51. Kim KH, Roberts CW: Targeting EZH2 in cancer. Nat Med 2016, 22 : $128-134$

52. Hohmann AF, Vakoc CR: A rationale to target the SWI/SNF complex for cancer therapy. Trends Genet 2014, 30:356-363

53. Wu RC, Wang TL, Shih Ie M: The emerging roles of ARID1A in tumor suppression. Cancer Biol Ther 2014, 15:655-664

54. Masliah-Planchon J, Bieche I, Guinebretiere JM, Bourdeaut F, Delattre O: SWI/SNF chromatin remodeling and human malignancies. Annu Rev Pathol 2015, 10:145-171 
55. Sanger F, Nicklen S, Coulson AR: DNA sequencing with chainterminating inhibitors. Proc Natl Acad Sci U S A 1977, 74: $5463-5467$

56. Ronaghi M, Uhlen M, Nyren P: A sequencing method based on realtime pyrophosphate. Science 1998, 281:363-365

57. Metzker ML: Sequencing technologies: the next generation. Nat Rev Genet 2010, 11:31-46

58. Mody RJ, Wu YM, Lonigro RJ, Cao X, Roychowdhury S, Vats P, Frank KM, Prensner JR, Asangani I, Palanisamy N, Dillman JR, Rabah RM, Kunju LP, Everett J, Raymond VM, Ning Y, Su F, Wang R, Stoffel EM, Innis JW, Roberts JS, Robertson PL, Yanik G, Chamdin A, Connelly JA, Choi S, Harris AC, Kitko C, Rao RJ, Levine JE, Castle VP, Hutchinson RJ, Talpaz M, Robinson DR, Chinnaiyan AM: Integrative clinical sequencing in the management of refractory or relapsed cancer in youth. JAMA 2015, 314:913-925

59. Meldrum C, Doyle MA, Tothill RW: Next-generation sequencing for cancer diagnostics: a practical perspective. Clin Biochem Rev 2011, 32:177-195

60. Chmielecki J, Meyerson M: DNA sequencing of cancer: what have we learned? Annu Rev Med 2014, 65:63-79

61. Frampton GM, Fichtenholtz A, Otto GA, Wang K, Downing SR, He J, et al: Development and validation of a clinical cancer genomic profiling test based on massively parallel DNA sequencing. Nat Biotechnol 2013, 31:1023-1031

62. Chiu RW, Lo YM: Non-invasive prenatal diagnosis by fetal nucleic acid analysis in maternal plasma: the coming of age. Semin Fetal Neonatal Med 2011, 16:88-93

63. Hoadley KA, Yau C, Wolf DM, Cherniack AD, Tamborero D, Ng S, Leiserson MD, Niu B, McLellan MD, Uzunangelov V, Zhang J, Kandoth C, Akbani R, Shen H, Omberg L, Chu A, Margolin AA, Van't Veer LJ, Lopez-Bigas N, Laird PW, Raphael BJ, Ding L, Robertson AG, Byers LA, Mills GB, Weinstein JN, Van Waes C, Chen Z, Collisson EA; Cancer Genome Atlas Research Network, Benz CC, Perou CM, Stuart JM: Multiplatform analysis of 12 cancer types reveals molecular classification within and across tissues of origin. Cell 2014, 158:929-944

64. Melo SA, Esteller M: Dysregulation of microRNAs in cancer: playing with fire. FEBS Lett 2011, 585:2087-2099

65. Schanen BC, Li X: Transcriptional regulation of mammalian miRNA genes. Genomics 2011, 97:1-6

66. Cao Q, Mani RS, Ateeq B, Dhanasekaran SM, Asangani IA, Prensner JR, Kim JH, Brenner JC, Jing X, Cao X, Wang R, Li Y, Dahiya A, Wang L, Pandhi M, Lonigro RJ, Wu YM, Tomlins SA, Palanisamy N, Qin Z, Yu J, Maher CA, Varambally S, Chinnaiyan AM: Coordinated regulation of polycomb group complexes through microRNAs in cancer. Cancer Cell 2011, 20:187-199

67. Saito Y, Liang G, Egger G, Friedman JM, Chuang JC, Coetzee GA, Jones PA: Specific activation of microRNA-127 with downregulation of the proto-oncogene BCL6 by chromatin-modifying drugs in human cancer cells. Cancer Cell 2006, 9:435-443

68. Varambally S, Cao Q, Mani RS, Shankar S, Wang X, Ateeq B, Laxman B, Cao X, Jing X, Ramnarayanan K, Brenner JC, Yu J, Kim JH, Han B, Tan P, Kumar-Sinha C, Lonigro RJ, Palanisamy N, Maher CA, Chinnaiyan AM: Genomic loss of microRNA-101 leads to overexpression of histone methyltransferase $\mathrm{EZH} 2$ in cancer. Science 2008, 322:1695-1699

69. Friedman JM, Liang G, Liu CC, Wolff EM, Tsai YC, Ye W, Zhou X, Jones PA: The putative tumor suppressor microRNA-101 modulates the cancer epigenome by repressing the polycomb group protein EZH2. Cancer Res 2009, 69:2623-2629

70. Dorsett Y, McBride KM, Jankovic M, Gazumyan A, Thai TH, Robbiani DF, Di Virgilio M, Reina San-Martin B, Heidkamp G, Schwickert TA, Eisenreich T, Rajewsky K, Nussenzweig MC: MicroRNA-155 suppresses activation-induced cytidine deaminasemediated Myc-Igh translocation. Immunity 2008, 28:630-638

71. Qi L, Bart J, Tan LP, Platteel I, Sluis T, Huitema S, Harms G, Fu L, Hollema H, Berg A: Expression of miR-21 and its targets (PTEN,
PDCD4, TM1) in flat epithelial atypia of the breast in relation to ductal carcinoma in situ and invasive carcinoma. BMC Cancer 2009, 9:163

72. Chan JA, Krichevsky AM, Kosik KS: MicroRNA-21 is an antiapoptotic factor in human glioblastoma cells. Cancer Res 2005, 65: 6029-6033

73. Folini M, Gandellini P, Longoni N, Profumo V, Callari M, Pennati M, Colecchia M, Supino R, Veneroni S, Salvioni R, Valdagni R, Daidone MG, Zaffaroni N: miR-21: an oncomir on strike in prostate cancer. Mol Cancer 2010, 9:12

74. Ma L, Teruya-Feldstein J, Weinberg RA: Tumour invasion and metastasis initiated by microRNA-10b in breast cancer. Nature 2007 , 449:682-688

75. Iyer MK, Niknafs YS, Malik R, Singhal U, Sahu A, Hosono Y, Barrette TR, Prensner JR, Evans JR, Zhao S, Poliakov A, Cao X, Dhanasekaran SM, Wu YM, Robinson DR, Beer DG, Feng FY, Iyer HK, Chinnaiyan AM: The landscape of long noncoding RNAs in the human transcriptome. Nat Genet 2015, 47:199-208

76. Cheetham SW, Gruhl F, Mattick JS, Dinger ME: Long noncoding RNAs and the genetics of cancer. Br J Cancer 2013, 108:2419-2425

77. Prensner JR, Iyer MK, Balbin OA, Dhanasekaran SM, Cao Q, Brenner JC, Laxman B, Asangani IA, Grasso CS, Kominsky HD, Cao X, Jing X, Wang X, Siddiqui J, Wei JT, Robinson D, Iyer HK, Palanisamy N, Maher CA, Chinnaiyan AM: Transcriptome sequencing across a prostate cancer cohort identifies PCAT-1, an unannotated lincRNA implicated in disease progression. Nat Biotechnol 2011, 29:742-749

78. Mehra R, Udager AM, Ahearn TU, Cao X, Feng FY, Loda M, Petimar JS, Kantoff P, Mucci LA, Chinnaiyan AM: Overexpression of the long non-coding RNA SChLAP1 independently predicts lethal prostate cancer. Eur Urol 2015, [Epub ahead of print] doi:10.1016/j. eururo.2015.12.003

79. Prensner JR, Iyer MK, Sahu A, Asangani IA, Cao Q, Patel L, Vergara IA, Davicioni E, Erho N, Ghadessi M, Jenkins RB, Triche TJ, Malik R, Bedenis R, McGregor N, Ma T, Chen W, Han S, Jing X, Cao X, Wang X, Chandler B, Yan W, Siddiqui J, Kunju LP, Dhanasekaran SM, Pienta KJ, Feng FY, Chinnaiyan AM: The long noncoding RNA SChLAP1 promotes aggressive prostate cancer and antagonizes the SWI/SNF complex. Nat Genet 2013, 45:1392-1398

80. Liz J, Esteller M: IncRNAs and microRNAs with a role in cancer development. Biochim Biophys Acta 2016, 1859:169-176

81. Prensner JR, Chen W, Han S, Iyer MK, Cao Q, Kothari V, Evans JR, Knudsen KE, Paulsen MT, Ljungman M, Lawrence TS, Chinnaiyan AM, Feng FY: The long non-coding RNA PCAT-1 promotes prostate cancer cell proliferation through cMyc. Neoplasia 2014, 16:900-908

82. Herceg Z, Hainaut P: Genetic and epigenetic alterations as biomarkers for cancer detection, diagnosis and prognosis. Mol Oncol 2007, 1:26-41

83. Otsuka J, Okuda T, Sekizawa A, Amemiya S, Saito H, Okai T, Kushima M: Detection of p53 mutations in the plasma DNA of patients with ovarian cancer. Int J Gynecol Cancer 2004, 14:459-464

84. Jackson PE, Kuang SY, Wang JB, Strickland PT, Munoz A, Kensler TW, Qian GS, Groopman JD: Prospective detection of codon 249 mutations in plasma of hepatocellular carcinoma patients. Carcinogenesis 2003, 24:1657-1663

85. Gormally E, Vineis P, Matullo G, Veglia F, Caboux E, Le Roux E, et al: TP53 and KRAS2 mutations in plasma DNA of healthy subjects and subsequent cancer occurrence: a prospective study. Cancer Res 2006, 66:6871-6876

86. Olivier M, Langerod A, Carrieri P, Bergh J, Klaar S, Eyfjord J, Theillet C, Rodriguez C, Lidereau R, Bieche I, Varley J, Bignon Y, Uhrhammer N, Winqvist R, Jukkola-Vuorinen A, Niederacher D, Kato S, Ishioka C, Hainaut P, Borresen-Dale AL: The clinical value of somatic TP53 gene mutations in 1,794 patients with breast cancer. Clin Cancer Res 2006, 12:1157-1167

87. Shigematsu H, Gazdar AF: Somatic mutations of epidermal growth factor receptor signaling pathway in lung cancers. Int J Cancer 2006 , 118:257-262 
88. Stefansson OA, Esteller M: Epigenetic modifications in breast cancer and their role in personalized medicine. Am J Pathol 2013, 183: 1052-1063

89. Fraga MF, Ballestar E, Villar-Garea A, Boix-Chornet M, Espada J, Schotta G, Bonaldi T, Haydon C, Ropero S, Petrie K, Iyer NG, PérezRosado A, Calvo E, Lopez JA, Cano A, Calasanz MJ, Colomer D, Piris MA, Ahn N, Imhof A, Caldas C, Jenuwein T, Esteller M: Loss of acetylation at Lys 16 and trimethylation at Lys 20 of histone $\mathrm{H} 4$ is a common hallmark of human cancer. Nat Genet 2005, 37:391-400

90. Salagierski M, Schalken JA: Molecular diagnosis of prostate cancer: PCA3 and TMPRSS2:ERG gene fusion. J Urol 2012, 187:795-801

91. Germenis AE, Karanikas V: Immunoepigenetics: the unseen side of cancer immunoediting. Immunol Cell Biol 2007, 85:55-59

92. Kim R, Emi M, Tanabe K: Cancer immunoediting from immune surveillance to immune escape. Immunology 2007, 121:1-14

93. Parcesepe P, Giordano G, Laudanna C, Febbraro A, Pancione M: Cancer-associated immune resistance and evasion of immune surveillance in colorectal cancer. Gastroenterol Res Pract 2016, 2016:6261721

94. Pardoll DM: The blockade of immune checkpoints in cancer immunotherapy. Nat Rev Cancer 2012, 12:252-264

95. Postow MA, Callahan MK, Wolchok JD: Immune checkpoint blockade in cancer therapy. J Clin Oncol 2015, 33:1974-1982

96. Herbst RS, Soria JC, Kowanetz M, Fine GD, Hamid O, Gordon MS, Sosman JA, McDermott DF, Powderly JD, Gettinger SN, Kohrt HE, Horn L, Lawrence DP, Rost S, Leabman M, Xiao Y, Mokatrin A, Koeppen H, Hegde PS, Mellman I, Chen DS, Hodi FS: Predictive correlates of response to the anti-PD-L1 antibody MPDL3280A in cancer patients. Nature 2014, 515:563-567

97. Taube JM, Klein A, Brahmer JR, Xu H, Pan X, Kim JH, Chen L, Pardoll DM, Topalian SL, Anders RA: Association of PD-1, PD-1 ligands, and other features of the tumor immune microenvironment with response to anti-PD-1 therapy. Clin Cancer Res 2014, 20:5064-5074

98. Weinstock M, McDermott D: Targeting PD-1/PD-L1 in the treatment of metastatic renal cell carcinoma. Ther Adv Urol 2015, 7: 365-377

99. Kim JW, Eder JP: Prospects for targeting PD-1 and PD-L1 in various tumor types. Oncology (Williston Park) 2014, 28(Suppl 3):15-28

100. Brahmer JR, Tykodi SS, Chow LQ, Hwu WJ, Topalian SL, Hwu P, Drake CG, Camacho LH, Kauh J, Odunsi K, Pitot HC, Hamid O, Bhatia S, Martins R, Eaton K, Chen S, Salay TM, Alaparthy S, Grosso JF, Korman AJ, Parker SM, Agrawal S, Goldberg SM, Pardoll DM, Gupta A, Wigginton JM: Safety and activity of anti-PDL1 antibody in patients with advanced cancer. N Engl J Med 2012, 366:2455-2465

101. Twyman-Saint Victor C, Rech AJ, Maity A, Rengan R, Pauken KE, Stelekati E, Benci JL, Xu B, Dada H, Odorizzi PM, Herati RS, Mansfield KD, Patsch D, Amaravadi RK, Schuchter LM, Ishwaran H, Mick R, Pryma DA, Xu X, Feldman MD, Gangadhar TC, Hahn SM, Wherry EJ, Vonderheide RH, Minn AJ: Radiation and dual checkpoint blockade activate non-redundant immune mechanisms in cancer. Nature 2015, 520:373-377

102. Beltran A, Parikh S, Liu Y, Cuevas BD, Johnson GL, Futscher BW, Blancafort P: Re-activation of a dormant tumor suppressor gene maspin by designed transcription factors. Oncogene 2007, 26: $2791-2798$

103. Gonzalgo ML, Nakayama M, Lee SM, De Marzo AM, Nelson WG: Detection of GSTP1 methylation in prostatic secretions using combinatorial MSP analysis. Urology 2004, 63:414-418

104. Thon N, Kreth S, Kreth FW: Personalized treatment strategies in glioblastoma: MGMT promoter methylation status. Onco Targets Ther 2013, 6:1363-1372
105. Mack GS: Epigenetic cancer therapy makes headway. J Natl Cancer Inst 2006, 98:1443-1444

106. Olsen EA, Kim YH, Kuzel TM, Pacheco TR, Foss FM, Parker S, Frankel SR, Chen C, Ricker JL, Arduino JM, Duvic M: Phase IIb multicenter trial of vorinostat in patients with persistent, progressive, or treatment refractory cutaneous T-cell lymphoma. J Clin Oncol 2007, 25:3109-3115

107. Hunter P: The second coming of epigenetic drugs: a more strategic and broader research framework could boost the development of new drugs to modify epigenetic factors and gene expression. EMBO Rep 2015, 16:276-279

108. Deisseroth A, Kaminskas E, Grillo J, Chen W, Saber H, Lu HL, Rothmann MD, Brar S, Wang J, Garnett C, Bullock J, Burke LB, Rahman A, Sridhara R, Farrell A, Pazdur R: U.S. Food and Drug Administration approval: ruxolitinib for the treatment of patients with intermediate and high-risk myelofibrosis. Clin Cancer Res 2012, 18: $3212-3217$

109. Ott M, Verdin E: HAT trick: p300, small molecule, inhibitor. Chem Biol 2010, 17:417-418

110. Fu LL, Tian M, Li X, Li JJ, Huang J, Ouyang L, Zhang Y, Liu B: Inhibition of BET bromodomains as a therapeutic strategy for cancer drug discovery. Oncotarget 2015, 6:5501-5516

111. Deng Y, Zhang Y, Sun S, Wang Z, Wang M, Yu B, Czajkowsky DM, Liu B, Li Y, Wei W, Shi Q: An integrated microfluidic chip system for single-cell secretion profiling of rare circulating tumor cells. Sci Rep 2014, 4:7499

112. Balic M, Lin H, Williams A, Datar RH, Cote RJ: Progress in circulating tumor cell capture and analysis: implications for cancer management. Expert Rev Mol Diagn 2012, 12:303-312

113. Zill OA, Greene C, Sebisanovic D, Siew L, Leng J, Vu M, Hendifar AE, Wang Z, Atreya CE, Kelley RK, Van Loon K, Ko AH, Tempero MA, Bivona TG, Munster PN, Talasaz A, Collisson E: Cellfree DNA next-generation sequencing in pancreatobiliary carcinomas. Cancer Discov 2015, 5:1040-1048

114. Naik SH, Schumacher TN, Perie L: Cellular barcoding: a technical appraisal. Exp Hematol 2014, 42:598-608

115. Mali P, Aach J, Lee JH, Levner D, Nip L, Church GM: Barcoding cells using cell-surface programmable DNA-binding domains. Nat Methods 2013, 10:403-406

116. Doudna JA, Charpentier E: Genome editing: the new frontier of genome engineering with CRISPR-Cas9. Science 2014, 346:1258096

117. Harrison MM, Jenkins BV, O'Connor-Giles KM, Wildonger J: A CRISPR view of development. Genes Dev 2014, 28:1859-1872

118. Siolas D, Hannon GJ: Patient-derived tumor xenografts: transforming clinical samples into mouse models. Cancer Res 2013, 73: 5315-5319

119. Aparicio S, Hidalgo M, Kung AL: Examining the utility of patient-derived xenograft mouse models. Nat Rev Cancer 2015, 15 : $311-316$

120. Hidalgo M, Amant F, Biankin AV, Budinska E, Byrne AT, Caldas C, Clarke RB, de Jong S, Jonkers J, Maelandsmo GM, Roman-Roman S, Seoane J, Trusolino L, Villanueva A: Patient-derived xenograft models: an emerging platform for translational cancer research. Cancer Discov 2014, 4:998-1013

121. Martinez-Garcia R, Juan D, Rausell A, Munoz M, Banos N, Menendez C, Lopez-Casas PP, Rico D, Valencia A, Hidalgo M: Transcriptional dissection of pancreatic tumors engrafted in mice. Genome Med 2014, 6:27

122. Boj SF, Hwang CI, Baker LA, Chio II, Engle DD, Corbo V, et al: Organoid models of human and mouse ductal pancreatic cancer. Cell 2015, 160:324-338 